\title{
Salus populi suprema lex: Godsdiensvryheid in krisistye \\ Salus populi suprema lex: Freedom of religion in times of crisis
}

\author{
Francois Venter \\ Fakulteit Regte, Noordwes-Universiteit \\ Potchefstroom \\ Suid-Afrika \\ E-pos: Francois.Venter@nwu.ac.za
}

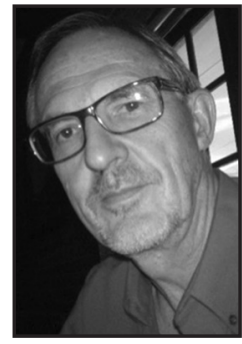

Francois Venter

Francois Venter is tans buitengewone professor in die Fakulteit Regte aan die NoordwesUniversiteit, waar hy van 2001 tot 2012 as dekaan gedien het. Hy ontvang tussen 1979 en 2019 gereeld toekennings van die Alexander-vonHumboldt-Stiftung vir navorsingsbesoeke aan Duitsland. Tydens die grondwetlike onderhandeling- en formuleringsproses van Mei tot Desember 1993 dien hy as sameroeper van die Tegniese Komitee oor Grondwetlike Aangeleenthede van die Veelparty-onderhandelingsproses. In 1998 bring hy die tans geakkrediteerde Potchefstroomse Elektroniese Regsblad as eerste van sy soort in Suid-Afrika tot stand en dien as redakteur daarvan tot in 2012. In 2011 en 2017 word hy deur die Nasionale Navorsingstigting (NNS) formeel gegradeer as 'n navorser "wat aansienlike internasionale erkenning van sy eweknieë vir die hoë gehalte en impak van sy onlangse navorsingsuitsette geniet". Hy is die outeur van verskeie monografieë, waaronder Constitutionalism and Religion (Edward Elgar Publishers, 2015) en Legal Research - Purpose, Planning and Publication (Juta, 2018).
Francois Venter is currently extraordinary professor at the Faculty of Law of the North-West University, where he served as dean from 2001 to 2012. Between 1979 and 2019, he regularly received research grants from the Alexander-vonHumboldt-Stiftung for research visits to Germany. During the negotiating process and formulation of the new Constitution, he served as convenor of the Technical Committee on Constitutional Affairs of the Multiparty Negotiation Process from May to December 1993. In 1998 he established the now accredited Potchefstroom Electronic Law Journal (PER), the first of its kind in South Africa, serving as its editor until 2012. In 2011 and 2017 he was rated by the National Research Foundation as a researcher "who enjoys considerable international recognition by his peers for the high quality and impact of his recent research outputs". He is the author of various monographs, including Constitutionalism and Religion (Edward Elgar Publishers, 2015) and Legal Research-Purpose, Planning and Publication (Juta, 2018).

\begin{tabular}{lll}
\hline Datums: & Goedgekeur: 2020-10-14 & Gepubliseer: Maart 2021 \\
Ontvang: 2020-06-13
\end{tabular}




\section{ABSTRACT}

\section{Salus populi suprema lex: Freedom of religion in times of crisis}

The role of the state in the religious life of citizens has been a constant issue since the emergence of the modern state. This is inevitable because, in the hands of the state, the law may be an instrument to limit religious freedom, causing believers to be confronted with the choice of either acting lawfully or obeying their conscience. No fundamental right is absolute, but at issue is whether state authorities should, when faced with a crisis, utilise their power to impose more restrictions than would normally be the case on citizens' religious rights. In this regard, the South African government's apparent disregard for citizens' rights during the pandemic crisis of 2020, caused widespread concern.

Exactly what "religious freedom" entails, is not evident. Section 15(1) of the Constitution provides a particularly dense, and therefore complex, characterisation: "Everyone has the right to freedom of conscience, religion, thought, belief and opinion." "Religion" may, on the one hand, be understood in a broad sense (including mysticism and mental phenomena such as some forms of Confucianism, Taoism and Buddhism, and non-devotional ontological views such as atheism and agnosticism); and, on the other, be regarded more narrowly, indicating attitudes or systems devoted to a single or multiple deities. Furthermore, "belief" may signify more than merely a view or attitude, but also refer to religious conviction. Religious freedom may be perceived as the first human right that received legal recognition as a fundamental right, historically dating back at least to the time of the Peace Treaty of Westphalia of 1648.

The notions of a "state of emergency" and the related instrument of "martial law" have deep and controversial roots in South African history. This explains the safeguards built into section 37 of the Constitution, which requires parliamentary oversight by the executive of the declaration and conduct of a state of emergency. Theoretically, the phrase salus reipublicae/ populi suprema lex has been associated with circumstances purportedly providing justification for the state to act in self-defence in times of war and civil unrest.

However, during the pandemic crisis of 2020, the government elected not to declare a state of emergency, as was the case in many other countries, but instead to muster extraordinary emergency powers based on an ordinary parliamentary statute, the Disaster Management Act 57 of 2002. However, the structures provided for in this Act were selectively used, and decision making was entrusted to a nebulous body with a rather revolutionary title, namely the "National Coronavirus Command Council", established without a clear legal framework. This body largely overlapped in structure and function with the cabinet and functioned in secrecy. Ominously, the president publicly associated the measures taken to deal with the pandemic and its economic consequences with "war".

The manner in which religious freedom may be limited constitutionally determines the assessment of the lawfulness of the effects of the disaster management arrangements on religious rights. Section 15(2) of the Constitution, which deals with the conditions pertaining to religious observances in state and state-aided institutions could not be realised, because the "lockdown" regulations prohibited religious gatherings in "recognized places of worship" such as churches, synagogues, mosques and temples.

These regulations and the concomitant actions were, in various respects, extraordinary and the lawfulness thereof, or of some aspects thereof, were consequently challenged from different perspectives, with interesting implications. In this regard, especially the "limitations clause" (section 36 of the Constitution) has to be noted. In addition, the dictum of the Constitutional Court in 2000 in the Christian Education case became particularly apposite: "Though there might be special problems attendant on undertaking the limitations analysis 
in respect of religious practices, the standard to be applied is the nuanced and contextual one required by 36 and not the rigid one of strict scrutiny." The "interpretation clause" of the Constitution (section 39), which requires the promotion of the values that underlie an open and democratic society based on human dignity, equality and freedom, might also have come into play, but its vagueness has thus far prevented the courts to provide much guidance for the application of this provision.

When the prohibition of religious gatherings was challenged before the Gauteng High Court (the Mohamed case), it was found to have been done lawfully in the name of the greater good, and that "[e]very citizen of this country needs to play his/her part in stemming the tide of what can only be regarded as an insidious and relentless pandemic".

Seen against the background of the inherent incompatibility of insistence on the primacy of the law with regard to prioritising religious convictions, especially given the religious plurality prevalent in South African society, it is submitted that some general principles apply.

KEYWORDS: $\quad$ Constitution; fundamental rights; freedom of religion; state of emergency; disaster management; pandemic; limitation of rights; legal order; state authority; socialism; democracy

TREFWOORDE: Grondwet; fundamentele regte; godsdiensvryheid; noodtoestand; rampbestuur; pandemie; beperkbaarheid van regte; regsorde; staatsgesag; sosialisme; demokrasie

\section{OPSOMMING}

Die rol van die staat in die geloofslewens van burgers is sedert die ontstaan van die moderne staat ' $n$ voortdurende kwessie. Dit is onvermydelik omdat die reg in die hande van die staat 'n instrument kan wees om godsdiensvryheid te beperk, wat kan meebring dat gelowiges voor die keuse geplaas kan word om, in gehoorsaamheid aan hul gewetens, onregmatig te handel. Geen fundamentele reg geld absoluut nie, maar die vraag ontstaan of staatowerhede tydens krisistye meer perke op burgers se godsdiensregte mag plaas as wat andersinds die geval sou wees? Hierdie vraag het weer na vore gekom tydens die regering se hantering van die pandemiekrisis van 2020. In hierdie bydrae word die grondwetlike verlening en die aard van die reg op godsdiensvryheid in Suid-Afrika eers kortliks behandel en dan in verband gebring met die onderskeie verskynsels van noodtoestand, krygswet en ramptoestand. Hoe die reg op godsdiensvryheid ingevolge die Grondwet beperk mag word, is bepalend vir die beoordeling van die regmatigheid van die uitwerking van die rampbestuursreëlings van 2020 op godsdiensvryheid. Hierdie maatreëls was in verskeie opsigte buitengewoon, en die regsgeldigheid daarvan, of van aspekte daarvan, is gevolglik ook uit verskeie perspektiewe betwis, wat interessante implikasies het. Gesien teen die agtergrond van die onmoontlikheid om aanspraak op die primaat van die reg met die prioriteit van religieuse oortuigings te versoen, des te meer nog te midde van religieuse pluraliteit, word bepaalde beginsels ter oorweging aan die hand gedoen.

\section{INLEIDING}

Ten tye van 'n nasionale krisis, soos 'n revolusie, 'n oorlog of 'n epidemie, word die gangbare sosiale, ekonomiese, politieke en kulturele orde, kortom die regsorde, versteur. Dit is dan 'n krisis wat deur "die owerhede" hanteer moet word. Wie "die owerheid" op 'n bepaalde tydstip in die wêreld en in 'n bepaalde land is wat die verantwoordelikheid moet en kan aanvaar om die krisis die hoof te bied, lê nie altyd voor die hand nie. 
As die krisis te doen het met die versteuring van internasionale vrede, 'n pandemie of die wêreldekonomie, kan internasionale strukture wat deur tussenstaatlike ooreenkomste tot stand gebring is, soos die Volkerebond, die Verenigde Nasies, die Wêreldgesondheidsorganisasie, die Internasionale Monetêre Fonds, en so meer, deel wees van die gesaghebbende owerhede. In dergelike gevalle word nasionale, regionale en plaaslike gesagsinstellings ook as deel van die verantwoordelike owerhede betrek.

In die geskiedenis het dit meermale gebeur dat die hantering van internasionale krisisse, met ' $n$ wisselende mate van sukses en geregtigheid, deur een of ander grootmoondheid oorheers is, omdat sodanige moondheid oor dominante militêre en ekonomiese mag beskik het. Bekende voorbeelde kan met die uitdrukkings Pax Romana, Pax Brittanica en selfs (met 'n korreltjie sout) Pax Americana in herinnering geroep word.

Wanneer sodanige krisis spesifieke implikasies vir die inwoners van 'n land het, staan die staat, met sy beheer oor die reg en al die gesagsinstrumente tot sy beskikking, voorop as die owerheid wat die krisis moet hanteer. Onder sulke omstandighede kan normale perke op die staatsowerhede se magte vervaag en kan die proses van beheer oor en herstel van die openbare orde gevolglik aanleiding gee tot brutale onreg, neutralisering van regsgefundeerde geregtigheid en onderdrukking van die samelewing of dele daarvan, asook beperkings op fundamentele regte.

In hierdie bydrae word die aandag beperk tot die staat as owerheid wat die verantwoordelikheid dra om krisissituasies te hanteer deur die regsorde met die regsgereguleerde gebruik van gesag te handhaaf. Om die fokus verder te vernou, word gekonsentreer op die mate waartoe godsdiensvryheid in krisistye deur die staat regmatig beperk mag word.

Eers word die grondwetlike verlening en die aard van die reg op godsdiensvryheid in Suid-Afrika kortliks as agtergrond vir 'n opsomming van die regsposisie rakende noodtoestande en ramptoestande uiteengesit. Daarna kom die vraag na die grondwetlik veroorloofde beperkbaarheid van godsdiensvryheid aan die orde, voordat die rampbestuursreëlings van 2020 en die implikasies daarvan vir die reg op godsdiensvryheid bespreek word. In afdeling 4 word die regverdigbaarheid van die beperking van die reg op godsdiensvryheid tydens krisisse behandel, waarna ten slotte kortliks besin word oor toepaslike beginsels vir die beoordeling van staatlike beperking van godsdiensvryheid.

\section{GODSDIENSVRYHEID, NOODTOESTAND EN RAMPTOESTAND}

Wat "godsdiensvryheid" regtens behels, lê nie sonder meer voor die hand nie. ${ }^{1}$ Dit is egter duidelik dat fundamentele regte in krisistye in gedrang kan kom. Veral twee regsbeperkende tipes krisisse kom ter sprake, naamlik noodtoestande en ramptoestande. In die Suid-Afrikaanse reg het hierdie twee begrippe verskillende tegniese betekenisse en implikasies, en noodtoestande as verskynsel het 'n lang en omstrede geskiedenis. ${ }^{2}$

In Currie, Iain \& De Waal, Johan. 2014. The Bill of Rights Handbook. Cape Town: Juta, p. 316, verwys die outeurs byvoorbeeld na die debat oor die betekenis van die woord "religion", wat na hul mening onnodig gemaak word deur artikel 15(1) van die Grondwet, omdat die bepaling ook ander regte (gewetensvryheid, denke, oortuiging, mening) beskerm, wat meebring dat die bepaling ook agnostisisme en ateïsme dek.

2 Sien bv. die Verslag van die Kommissie van Ondersoek na Aangeleenthede betreffende die Veiligheid van die Staat (die "Potgieter-kommissieverslag") RP 102/1971; Mathews, AS. 1977. Law, Order and Liberty in South Africa. Cape Town: Juta, veral hoofstuk XVIII; Du Plessis, W \& Olivier, N. 9 Januarie 1987 - Verdere beperkende noodmaatreels. SA Publiekreg/Public Law, 2(1):84-88; Du

Tydskrif vir Geesteswetenskappe, Jaargang 61 No. 1: Maart 2021

doi.10.17159/2224-7912/2021/v61n1a8 


\subsection{Godsdiensvryheid}

Artikel 15(1) van die Grondwet van 1996 lui: "Elkeen het die reg op vryheid van gewete, godsdiens, denke, oortuiging en mening." (Die Engelse weergawe van die Grondwet (Constitution of the Republic of South Africa, 1996) is die enigste amptelike teks. Artikel 15(1) daarvan lui: "Everyone has the right to freedom of conscience, religion, thought, belief and opinion.") Die fundamentele reg wat deur hierdie bepaling aan almal verleen word, is kompleks van aard. Waarop "gewetensvryheid" en "meningsvryheid" dui, is miskien duideliker as "godsdiensvryheid" ("freedom of religion") en wat as "vryheid van oortuiging" uit die Engelse "freedom of belief" vertaal is.

Die Afrikaanse woordgroep "godsdiens", "geloof", "oortuiging" en "religie" is eintlik meer genuanseerd as die Engelse "religion" en "belief" en kan dus nie sonder meer met die enkelbegrippe soos in die aangehaalde Afrikaanse vertaling van artikel 15(1) weergegee word nie. "Religion" neem nie altyd net die vorm van godsdiens aan nie. Daar is religieë wat nie "godsdiens" genoem kan word nie, omdat die aanhangers daarvan geen gode aanbid nie, maar byvoorbeeld eienskappe eie aan die menslike gees, soos die bewussyn en mistiek, voorop stel (bepaalde vorms van Konfusianisme, Taoïsme en Boeddhisme is voorbeelde hiervan). In dieselfde kader is waarskynlik die mees invloedryke lewensbeskouing in die Westerse wêreld, die rasionalisme, wat die menselike rede verheerlik. Dit word natuurlik selde as 'n religie beskou, maar verteenwoordig net so 'n fundamentele ontologiese oortuiging as enige van die hoofstroomgodsdienste. Verder kan die Engelse begrip "belief" veel meer as blote "mening" aandui, maar ook oortuiging, geloof, opvatting en so meer. In hierdie bydrae word "religie" in die breedste sin, naamlik sowel godsdienstige as nie- en anti-godsdienstige lewensoortuigings, gebruik.

Dit is nie geleë om hier verder op die potensiële spraakverwarring rakende die begrip "godsdiensvryheid" in te gaan nie, anders as om te beklemtoon dat dit in artikel 15(1) handel oor die reg op 'n vryheid. Die onderskeid tussen hierdie twee begrippe is ook potensieel kompleks, want hoewel hulle dikwels in samehang met mekaar gebruik word, dra hulle duidelik onderskeibare betekenisse. Eenvoudig gestel, 'n reg verleen 'n aanspraak op iets, terwyl 'n vryheid 'n verbod op eksterne inmenging impliseer.

Hoewel slegs artikel 15(1) spesifiek oor die reg op godsdiensvryheid handel, het verskeie ander bepalings van die Grondwet betrekking op die genieting van godsdiensvryheid. Daarop word hier onder in afdeling 2 teruggekom, maar interessantheidshalwe kan ook gemeld word dat artikel 35(2)(f)(iii) van die Grondwet aan gearresteerde, aangehoue en beskuldigde persone die reg verleen om in verbinding te tree met en besoek te word deur 'n godsdiensraadgewer ("religious counsellor") van hul eie keuse.

Histories is dit interessant dat die verlening van godsdiensvryheid soos dit vandag in die dominante (Westerse) grondwetlike woordeskat voorkom, beskryf kan word as die eerste wat as "mensereg", en dus as regsbeskermde fundamentele reg, erken is en dat dit voortgevloei het uit die gebeure wat onder meer tot die vorming van die moderne staat en die skeiding tussen kerk en staat aanleiding gegee het. Die gebeure wat hier ter sprake is, is die onderhandeling en sluiting van 'n reeks verdrae waardeur dekadelange godsdiensoorloë in Europa tot 'n einde gebring is, naamlik die Vrede van Wesfale van $1648 .^{3}$

Plessis, W \& Olivier, N. 11 Junie 1987 - Tweede Algemene Noodtoestand. SA Publiekreg/Public Law 2(2):197-207; Venter, F. 1988. Krygswet en noodtoestand. SA Publiekreg, 3(1):1-22.

3 Vgl. bv. Venter, F. 2015. Constitutionalism and Religion. Cheltenham: Edward Elgar Publishers, pp. 20-21 en die bronne daar aangehaal. 
Wat verder hier ter sake is, is die gegewe dat die staat gewoonlik steeds die magtigste sosiale entiteit is wat op godsdiensvryheid inbreuk kan maak. As die staat in 'n krisistyd so handel dat die vryheid van individue of groepe mense om hul godsdiens te beoefen, beperk word, of tot niet gemaak word, word die reg op godsdiensvryheid as sodanig, dit wil sê die reg om vry te wees en te glo wat jy wil, nie noodwendig geskend nie, maar ander grondwetlikverleende en verskanste regte wel.

\subsection{Noodtoestand en krygswet}

Weens Suid-Afrika se onstuimige voorgrondwetlike geskiedenis, toe noodtoestande skerp binnelandse politieke dimensies gehad het, is spesifieke aandag daaraan tydens die skryf van die Grondwet gegee. ${ }^{4}$ Dit het gelei tot die insluiting by die Handves van Regte van die besonder uitgebreide artikel 37 van die Grondwet, wat streng beperkings op die regering plaas. Verder het die parlement 'n wet oor noodtoestande aangeneem. ${ }^{5}$ Die aanname van so 'n wet word deur artikel 37(1) van die Grondwet vereis, wat ook die beperkte omstandighede waaronder 'n noodtoestand verklaar mag word, lys:

(1) 'n Noodtoestand mag slegs ingevolge 'n Parlementswet verklaar word en slegs wanneer -

(a) die voortbestaan van die nasie deur oorlog, 'n inval, algemene oproer, wanorde, 'n natuurramp of ' $n$ ander openbare noodgeval bedreig word; en

(b) die verklaring nodig is om die vrede en orde te herstel.

Ingevolge artikel 1 van die Wet mag die president met opgaaf van die redes daarvoor en met inagneming van artikel 37 van die Grondwet 'n noodtoestand by proklamasie in die Staatskoerant verklaar. Die Nasionale Vergadering het oorsig oor die noodtoestandreëlings en die duur daarvan. Die eerste verklaring van so 'n noodtoestand mag ingevolge artikel 37(2) slegs vir 21 dae van krag wees, waarna die Nasionale Vergadering dit ná openbare debatvoering vir periodes van hoogstens drie maande op 'n keer mag verleng.

Wat die verklaring van 'n noodtoestand so sensitief maak, is dat dit histories gewortel is in voorvalle van oorlog en openbare oproer - vandaar die frase "nodig is om vrede en orde te herstel" in artikel 37(1)(b) van die Grondwet. Die verklaring van 'n noodtoestand is voorheen hoofsaaklik met die handhawing van staatsveiligheid geassosieer en meermale verbind aan die stelreël salus reipublicae suprema lex (letterlik "die gesondheid/welsyn/veiligheid van die staat is die hoogste reg").

Die noodtoestand waarvoor artikel 37 van die Grondwet voorsiening maak, kan wel onder meer betrekking hê op oorlog, maar die fokus daarvan (soos uit subartikel 37(1)(b) blyk) is om die herstel van versteurde vrede en orde in die land te bewerkstellig. Die verklaring van 'n noodtoestand sou dus (onder meer) gemotiveer kon word indien daar as gevolg van 'n ramp "algemene oproer" of "wanorde" ontstaan wat (net) met buitengewone maatreëls bekamp kan word.

In sake wat uit die land se onstuimige politieke geskiedenis voortgespruit het, het die howe meermale na die spreuk salus reipublicae suprema lex (waarvan die presiese historiese

\footnotetext{
$4 \quad$ Vgl. bv. Erasmus, G. 1994. Limitation and Suspension. In Van Wyk et al. (eds). Rights and Constitutionalism - The New South African Legal Order. Cape Town: Juta, pp. 650-651. State of Emergency Act 64 van 1997.
} 
herkoms onseker is) verwys, byvoorbeeld in 1965 waar die hooggeregshof die spreuk soos volg in die Baker- en Doyle-saak gebruik het:

The State has an inherent right and duty to defend itself. It is experienced in the doctrine: salus reipublicae suprema lex. This is a doctrine which we have taken over from English constitutional law and it is a doctrine recognised by all States. ${ }^{6}$

Soms word alternatiewe begrippe in die stelreël ná "salus" geplaas, byvoorbeeld "populi" (die mense/bevolking/gemeenskap), of net "publica" (die publiek). Verwante stellings wat private belange onderhewig aan openbare belange stel, kom ook voor, byvoorbeeld "necessitas publica major est quam privata" en "in casu extremae necessitatis omnia sunt communia". Wat ook al die herkoms van die spreuk salus reipublicae suprema lex is, in die Engelse reg is dit ten minste sedert die sestiende eeu gebruik en in die koloniale era ook in Suid-Afrika toegepas. ${ }^{7}$

"Staatsveiligheid" is 'n begrip sonder 'n statutêre definisie, maar word geredelik in verband gebring met begrippe soos "openbare veiligheid", meestal ontleen aan oorlogswetgewing. 'n Voorbeeld hiervan is te vinde in die Krijgswet Proklamatie van 1914, wat weens die uitbreek van die Eerste Wêreldoorlog uitgevaardig is. Daarin was sprake van "openbare veiligheid" ("public safety"). In Proklamasie 201 van 1939, wat met die uitbreek van die Tweede Wêreldoorlog uitgevaardig is, is weer melding gemaak van 'n "landsnoodtoestand" ("state of national emergency") "wat die veiligheid van die Staat" ("security of the State") in gevaar kon bring en buitengewone arrestasies "in staatsbelang” gemagtig het.

Tydens die bestaan van krygswet word die owerheidsgesag primêr in die hande van die militêre owerheid geplaas, hetsy deur die professionele hoof van die weermag aan bewind te plaas, hetsy deur die gewone regering te militariseer deur daaraan primêr militêre funksies te verleen, terwyl noodtoestandsreëlings veronderstel dat buitengewone addisionele gesag aan die gewone burgerlike owerhede verleen word om die noodtoestand mee die hoof te bied, terwyl die militêre magte bloot tot hulle ondersteuning aangewend kan word. ${ }^{8}$

Krygswet is dus 'n ekstreme vorm van noodtoestand wat tipies in buitengewone omstandighede uitgeroep word om die voortbestaan van die staat in noodweer te probeer handhaaf, soos waar die land in 'n vernietigende oorlog betrokke raak of wanneer 'n volskaalse burgeroorlog uitbreek. Krygswet is onbestaanbaar met die huidige Suid-Afrikaanse Grondwet, aangesien die owerhede, veral die militêre gesagstrukture, onder krygswet vir hulleself ' $n$ vrye diskresie in die uitoefening van hul mag, ongeag normale regsnorme, aanmatig.

Artikel 203 van die Grondwet ruim wel die moontlikheid vir die president in om, met die instemming van die parlement, 'n "nasionale verdedigingstoestand" ("state of national defence") te verklaar. Dit het klaarblyklik met oorlogvoering te doen, en die Verdedigingswet bevat verdere reëlings in verband daarmee. Ingevolge artikel 89 van hierdie wet $^{9}$ kan die president 'n verdedigingstoestand verklaar wanneer (met die vae kwalifikasie "among other things") die soewereiniteit van die Republiek deur "war, including biological or chemical warfare, or invasion, armed attack or armed conflict" bedreig word; of, "is being or has been

Sv Baker; Sv Doyle [1965] 1 All SA 362 (W) 369-370.

Vgl. Venter, F. 1977. Salus reipublicae suprema lex. Tydskrif vir Hedendaagse Romeins-Hollandse Reg, 40:233-252, 235-237.

8 Venter, F. 1988. Krygswet en noodtoestand. SA Publiekreg/Public Law, 3(1):1-22, 21.

$9 \quad$ Defence Act 42 van 2002. 
invaded or is under armed or cyber attack or subject to a state of armed conflict". Artikel 203 vereis dat die parlement 'n presidensiële verklaring van 'n verdedigingstoestand binne sewe dae vanaf die verklaring daarvan moet goedkeur, by ontstentenis waarvan dit verval. Hoewel die verklaring van 'n verdedigingstoestand klaarblyklik nie bedoel is om soos krygswet te funksioneer nie (die Verdedigingswet se uitleg bly onderhewig aan die Grondwet), het dit wel betrekking op militêre oorlogvoering (in teenstelling met byvoorbeeld 'n "stryd" teen 'n epidemiese toestand).

Artikel 201 van die Grondwet magtig die president om die weermag aan te wend (“employ"), selfs in die afwesigheid van 'n verdedigingstoestand, 'n noodtoestand of 'n ramptoestand. Dit mag gebeur as die president oordeel dat dit nodig is om die weermag ter ondersteuning van die polisie aan te wend, ter verdediging van die Republiek of om aan 'n internasionale verpligting te voldoen. Die president moet die parlement so spoedig moontlik ("promptly") oor die redes en ander besonderhede rakende sodanige aanwending inlig.

Wanneer ' $n$ buitengewone situasie opduik wat na die oordeel van die uitvoerende gesag buitengewone uitoefening van staatsgesag vereis, waardeur grondwetlik beskermde regte ingeperk word, is daar verskeie oorvleuelende grondwetlik geoorloofde meganismes beskikbaar. Die verklaring van krygswet is nie een daarvan nie, maar wel die verklaring van 'n noodtoestand, die verklaring van 'n verdedigingstoestand en die ontplooiing van die weermag met of sonder die bestaan van 'n nood- of verdedigingstoestand. In al hierdie gevalle word voorsiening gemaak vir parlementêre oorsig en goedkeuring en beperking van die duur van die uitsonderlike situasie.

Uitdruklike grondwetlike voorsiening word gemaak vir uitsonderings op die beskerming van fundamentele regte (“derogation") slegs in gevalle waar 'n noodtoestand verklaar word. Benewens die normale beperkbaarheid van fundamentele regte wat hier onder in afdeling 2 bespreek word, en "derogation" tydens 'n regsgeldig-verklaarde noodtoestand, is daar dus geen spesiale grondwetlike regverdiging vir inbreukmaking deur die staat op fundamentele regte nie.

\subsection{Ramptoestand}

Met die uitbreek van die globale pandemie-krisis vroeg in 2020 was buitengewone owerheidsoptrede onvermydelik. Die Suid-Afrikaanse regering het verkies om, anders as baie ander lande (waaronder Botswana, Etiopië, Hongarye, Japan, Spanje en die meeste deelstate van die $\mathrm{VSA}^{10}$ ) nie 'n noodtoestand te verklaar nie, maar gebruik te maak van die Wet op Rampbestuur. ${ }^{11}$ Die doel van dié Wet, soos beskryf in die lang titel daarvan, is om voorsiening te maak vir 'n geïntegreerde en gekoördineerde rampbestuursbeleid wat daarop gemik is om die risiko van rampe te voorkom of te verminder, en vinnige en effektiewe reaksie op rampe en herstel ná rampe te bied. 'n Ramp word in artikel 1 van die Wet gedefinieer as 'n progressiewe of skielike, wydverspreide of gelokaliseerde natuurlike of deur die mens veroorsaakte gebeurtenis, wat die oorsaak is of die dreigement inhou van siekte, skade aan eiendom, infrastruktuur of die omgewing, of die lewensontwrigting van 'n gemeenskap, en wat van sodanige omvang is dat dit diegene wat daardeur geraak word se vermoë oorskry.

\footnotetext{
10 Sien bv. International Monetary Fund. 2020. https://www.imf.org/en/Topics/imf-and-covid19/ Policy-Responses-to-COVID-19 [2 September 2020].

$11 \quad$ Disaster Management Act 57 van 2002.
} 
Die pandemie pas volledig in hierdie definisie, behalwe dat dit onwaarskynlik is dat die Wet nagenoeg twintig jaar gelede ontwerp is om so 'n omvattende krisis soos die pandemie te hanteer. 'n Aanduiding (weliswaar by implikasie) daarvan is die beperking wat in artikel 2(1)(a) van die Wet op die toepassing daarvan geplaas is:

2. (1) This Act does not apply to an occurrence falling within the definition of "disaster" in section 1 -

(a) if, and from the date on which, a state of emergency is declared to deal with that occurrence in terms of the State of Emergency Act, 1997

Die implikasie is dat in die geval van buitengewone owerheidsoptrede waardeur maatskaplike ontwrigting deur staatsoptrede meegebring word (in teenstelling met owerheidshantering van ontwrigting wat op ander maniere ontstaan), die afkondiging van 'n noodtoestand aangewese is eerder as die verklaring van 'n ramptoestand.

'n Tweede aanduiding in die Wet op Rampbestuur dat dit nie ontwerp is om inbreukmaking op die grondwetlik beskermde fundamentele regte te veroorloof nie, is dat daar in die wetsteks, anders as in artikel 37 van die Grondwet, geen melding gemaak word van die moontlike uitwerking van die verklaring van 'n ramptoestand op die fundamentele regte wat deur die Handves van Regte verskans word nie.

Derdens maak die Wet geen voorsiening vir parlementêre goedkeuring ná 'n aanvanklike periode van die verklaring van 'n ramptoestand, soos in die geval van die afkondiging van 'n noodtoestand nie, of vir regstreekse parlementêre toesig oor die maatreëls wat ingevolge die Wet ingestel word nie. ${ }^{12}$ Verder maak artikel 27 van die Wet daarvoor voorsiening dat die minister aan wie die president die administrasie van die Wet opdra, 'n ramptoestand mag verklaar en dan regulasies en aanwysings ("directions") kan uitreik, of die uitreiking daarvan in effek kan delegeer. Hierdie "tweedevlak"-reëling kontrasteer skerp met die verklaring van 'n noodtoestand of 'n verdedigingstoestand wat slegs deur die president, met noodsaaklike betrokkenheid van die parlement, toelaatbaar is.

Artikel 4 van die Wet reël die skepping van 'n “intergovernmental committee on disaster management", wat bestaan uit regeringsfunksionarisse uit die kabinet, provinsiale uitvoerende komitees en munisipale rade wat onder die voorsitterskap van die minister verantwoordelik vir rampbestuur funksioneer. So 'n komitee is in 2016 tot stand gebring. ${ }^{13}$ Artikel 5 maak voorsiening vir die totstandbrenging op senioramptenaarsvlak en 'n lang lys rolspelers uit die burgerlike gemeenskap met die oog op wedersydse konsultasie en koördinering. Artikels 9 tot 24 van die Wet reël die skepping en bestuur van 'n permanente Nasionale Rampbestuursentrum wat, onder leiding van 'n staatsamptenaar as hoof, die taak het om 'n geïntegreerde en gekoördineerde rampbestuurstelsel op alle regeringsvlakke te bevorder.

Toe die ramptoestand in 2020 verklaar is, het die regering nie van die statutêre strukture waarvoor artikels 4 en 5 voorsiening maak, gebruik gemaak nie, maar die president het 'n "National Coronavirus Command Council" (NCCC) uit die niet, dit wil sê sonder 'n grondwetlike of statutêre onderbou of struktuur, in die lewe geroep. Dit is nie duidelik watter ministers almal lede van die NCCC geword het, of al die lede van die kabinet by tye daarby

\footnotetext{
12 Artikel 3 van die State of Emergency Act, 1997 vereis die onmiddellike tertafellegging van die president se proklamasie waarin 'n noodtoestand afgekondig word, asook die gepaardgaande reëlings, in die parlement, wat dit dan kan afkeur of die aanpassing daarvan kan aanbeveel. Proklamasie R.61 van 2016 in Staatskoerant 40394 van 2 November 2016.
} 
betrek is en presies wat die verhouding en besluitnemingsinteraksie tussen individuele ministers, hul onderskeie departemente, die kabinet as die grondwetlike setel (onder die aanvoering van die president) van die uitvoerende gesag, en die NCCC moes wees nie. In 'n brief van 4 Mei 2020 van die direkteur-generaal van die presidensie en sekretaris van die kabinet aan 'n prokureursfirma is verduidelik dat die NCCC "is a coordinating body, just as other Cabinet structures are coordinating bodies, established to facilitate the work of the relevant Cabinet members and Cabinet as whole, and given authority by Cabinet to do just that." 14 Die regering het aangedui dat die verrigtinge en funksionering van die NCCC as "geheim" geklassifiseer is. Die benaming van die liggaam herinner onheilspellend aan revolusionêre strukture soos die Irakese Revolutionary Command Council van 2003 en Sudan se National Revolutionary Command Council wat ná 'n staatsgreep van 1969 tot stand gebring is. Dit resoneer ook met die beleidstaal van die ANC bekend as die "National Democratic Revolution". Ten tye van die skryf hiervan is die regsgeldigheid van die skepping en funksionering van die NCCC nog nie in die howe getoets nie, hoewel dit in die Gautengse hooggeregshof se uitspraak van 15 Mei 2020 in die Khosa-saak die "nebulous National Command Council" genoem is. ${ }^{15}$

Die manier waarop die regering die pandemiekrisis in 2020 benader het, kan beskryf word as geheime, gesentraliseerde besluitneming oor die hantering van die ramptoestand. Besluite van hierdie uitsonderlike (revolusionêre?) liggaam (die NCCC) is klaarblyklik bedoel om buite die bereik van eksterne kontrolemeganismes te funksioneer. Die implikasie van die benaming daarvan was dat die NCCC beklee moes word met bevelsgesag oor alle owerheidsfunksies deur die gebruik van geselekteerde implementeringsmeganismes waarvoor in die rampbestuurswetgewing voorsiening gemaak word. Dit kan verstaan word as 'n oorwoë strategie om die beperkings en oorsigmeganismes waarvoor onder meer artikel 37 van die Grondwet in gevalle van noodtoestande voorsiening maak, te omseil.

Aan die ander kant van die munt kan geargumenteer word dat daar, in die gees van salus populi suprema lex (letterlik verstaan as die prioriteit van die beskerming van die gesondheid van die bevolking) gegronde redes was vir die skep van strukture wat nodig was vir die neem van dringende besluite. ' $n$ Blywende kwelling is egter in watter mate die verleidelikheid van hierdie vorm van regering vir die ANC, met bewese sosialistiese neigings, langtermynimplikasies vir die staatsregtelike toekoms van die land inhou. ${ }^{16}$ President Ramaphosa het die stryd teen die pandemie meermale in die media vergelyk met 'n oorlog en regstreekse vergelykings getref tussen die manier waarop ekonomiese herstel ná die ramptoestand bewerkstellig sal moet word en die manier waarop dit tipies ná 'n oorlog verloop.

Wat nietemin tans nog vasstaan, is dat die bepalings van die Grondwet die bepalings van die Wet op Rampbestuur en enige optrede van owerhede troef. Anders gestel, geen optrede wat voortspruit uit die toepassing van die Wet of optrede deur die kabinet wat in stryd is met die Grondwet, is regmatig nie. Dit is die onderliggende beginsel wat ook baie duidelik en herhaaldelik herbevestig is in die uitspraak in die bogemelde Khosa-saak, juis met verwysing na die toepaslike wetgewing en maatreëls wat in 2020 tydens die verklaarde ramptoestand getref is. Daar kan verwag word dat meer regtelike lig op die regmatigheid en grondwetlike

14 RHK Attorneys het die brief elektronies beskikbaar gestel by RHK Attorneys. 2020. https://www. scribd.com/document/460238622/RHK-Attorneys04May20\#download\&from embed (geraadpleeg op 1 Augustus 2020).

$15 \quad$ Khosa $v$ Minister of Defence and Military Veterans, para 73.

16 Vgl. Venter, F. 2020. Staatsregtelike behoorlikheid in die 21ste eeu. Tydskrif vir Geesteswetenskappe, 60(3):par. 5. 
houdbaarheid van regeringsoptrede tydens die krisis gewerp sal word in die uitsprake van verskeie sake waarin litigante hulle tot die howe gewend het. ${ }^{17}$

'n Eerste aanduiding van judisiële simpatie met die regering se benutting van die rampbestuursmeganismes in plaas van die grondwetlike veroorlowing en regulering van noodtoestande het in Julie 2020 na vore gekom in 'n volbankuitspraak van die hooggeregshof in Pretoria. Die hof het 'n aansoek om elemente van die Wet op Rampbestuur ongrondwetlik te verklaar, van die hand gewys, hoofsaaklik op sterkte van die siening dat waar 'n noodtoestand afwyking van die normale grondwetlike orde toelaat, dit nie die geval met 'n ramptoestand is nie. ${ }^{18}$ Dit sal interessant wees om die verdere verwikkelinge in hierdie verband te volg, maar aangesien die betrokke sake op hierdie stadium weinig betrekking het op godsdiensvryheid as sodanig, word dit vir die huidige doeleindes daargelaat.

\section{GRONDWETLIK VEROORLOOFDE BEPERKBAARHEID VAN GODS- DIENSVRYHEID}

In 1.1 hier bo is na die grondwetlike oorsprong van die verlening van die reg op godsdiensvryheid verwys. Artikel 15(2) van die Grondwet bevat bepalings wat sekere beperkings op dié reg plaas, ietwat eienaardig geformuleer in die vorm van 'n toegewing. 'n Afrikaanse weergawe daarvan lui soos volg:

(2) Godsdiensbeoefening kan by staats- of staatsondersteunde instellings geskied, mits -

(a) daardie beoefening reëls nakom wat deur die tersaaklike openbare gesag gemaak is;

(b) dit op billike grondslag geskied; en

(c) bywoning daarvan vry en vrywillig is.

Die (gesaghebbende) Engelse bewoording bevat nuanses wat moontlik deurslaggewend kan wees vir die vertolking van hierdie bepaling. Die ekwivalent van "godsdiensbeoefening" is

17 Die geldigheid of grondwetlikheid van die rampmaatreëls is in 'n hele reeks sake voor verskillende afdelings van die hooggeregshof betwis, (sien bv. $<$ http://www.saflii.org/cgi-bin/sinosrch-adw. cgi?query=COVID-19\%20or $\% 20$ coronavirus $\% 20 ;$ submit $=$ Search; view $=$ databasenatural; offset $=0>$ [1 September 2020]), maar ten tyde van die skrywe hiervan is heelwat uitsprake, en veral bevindings op appèl, nog uitstaande.

18 Freedom Front Plus v President of the Republic of South Africa (22939/2020) [2020] ZAGPPHC 266 (6 July 2020). Sleutelparagrawe in die uitspraak oor hierdie punt lui soos volg:

65. The [Disaster Management Act] does not permit a deviation from the normal constitutional order. It permits the executive to enact regulations or issue directions. It may well be that these regulations will limit fundamental rights. But the fundamental rights remain intact in the sense that any limitation is still subject to being tested against $\mathrm{s} 36$ of the Constitution. For this simple reason, it is not for the DMA to include a specific provision preserving the competence of courts to rule on the validity of regulations. Under states of disaster, this competence remains intact: It is never removed or suspended to begin with.

66 . The courts may review a declaration of a state of disaster, any extension of a state of disaster, and any regulations enacted under a state of disaster under their ordinary powers to review the exercise of any public power. This power may be exercised under the principle of the rule of law entrenched in section 1(c) of the Constitution, and all the provisions of the Bill of Rights, including section 33 read with the Promotion of Administrative Justice Act. The courts' powers of review accordingly remain entirely unimpaired under a national state of disaster. The same holds true for the safeguard provided in $\mathrm{s} 37(5)$ of the Constitution, which prohibits the state from granting indemnities in respect of unlawful acts. 
"religious observances". Die beoefening van godsdiens kan natuurlik verskillende vorme aanneem, wat byvoorbeeld persoonlike individuele of groepsoordenking, meditasie, gebed, vas-, liturgiese en gebarerituele en die nakoming van godsdienstige kleredragvoorskrifte kan insluit, sowel as die verkondiging van religieuse leerstellings. Of die Engelse uitdrukking "religious observance" 'n meer beperkte betekenis dra, byvoorbeeld net omskrewe groepsbyeenkomste van godsdienstige aard, is nie seker nie. Verder is die Engelse ekwivalent van "kan" in die inleidende frase "may", wat ook in Afrikaans as 'n veroorlowende "mag" vertaal sou kon word in plaas van 'n aanduiding van vermoë ("can" in Engels). Aan die einde van die inleidende frase is die Engelse "provided that" in die bostaande vertaling met "mits" weergegee. Die meer gebruiklike Afrikaanse ekwivalent hiervoor is "met dien verstande dat".

Positief vertolk kan artikel 15(2) beteken dat godsdienstige handelinge by staatsverwante instellings vryelik kan plaasvind, slegs onderhewig aan die voorwaardes vermeld in (a) tot (c). Negatief gesien, kan dit verstaan word as 'n verbod in beginsel op godsdiens by staatsinstellings, behalwe as die nodige toestemming daarvoor uitdruklik verleen word.

Hoe dit ook al sy, die beperking (of veroorlowing) van artikel 15(2)(a) tot (c) het net betrekking op die beoefening van godsdiens by staatsverwante instellings en raak godsdienshandelinge op ander plekke, soos in die openbaar, in kerke, moskees, sinagoges, tempels, en so meer, dus glad nie. Na die gronde vir regmatige beperking van godsdiensvryheid oor die algemeen moet dus elders in die Grondwet gesoek word.

Geen fundamentele reg het absolute gelding nie. Al die regte in die Handves van Regte is dus op die een of ander manier beperkbaar, wel binne die raamwerk wat die Handves self daarvoor stel. Die bogemelde subparagrawe van artikel 15(2) behels 'n tipiese "interne" beperking, dit wil sê 'n beperking wat op die spesifieke reg (op godsdiensbeoefening) betrekking het. Artikel 36 van die Grondwet skep egter die algemene raamwerk waarbinne die grondwetlike regte, dus ook die reg op godsdiensvryheid, beperk mag word:

(1) Die regte in die Handves van Regte kan slegs kragtens 'n algemeen geldende regsvoorskrif beperk word in die mate waarin die beperking redelik en regverdigbaar is in 'n oop en demokratiese samelewing gebaseer op menswaardigheid, gelykheid en vryheid, met inagneming van alle tersaaklike faktore, met inbegrip van -

(a) die aard van die reg;

(b) die belangrikheid van die doel van die beperking;

(c) die aard en omvang van die beperking;

(d) die verband tussen die beperking en die doel daarvan; en

(e) 'n minder beperkende wyse om die doel te bereik.

(2) Behalwe soos in subartikel (1) of in enige ander bepaling van die Grondwet bepaal, mag geen regsvoorskrif enige reg wat in die Handves van Regte verskans is, beperk nie.

Die konstitusionele hof het in 2000 soos volg rigtinggewend oor die beperking van die reg op godsdiensvryheid beslis:

[L]imitations on constitutional rights can pass constitutional muster only if the Court concludes that, considering the nature and importance of the right and the extent to which it is limited, such limitation is justified in relation to the purpose, importance and effect of the provision which results in this limitation, taking into account the availability of less restrictive means to achieve this purpose. Though there might be special problems attendant on undertaking the limitations analysis in respect of religious practices, the 
standard to be applied is the nuanced and contextual one required by s 36 and not the rigid one of strict scrutiny. ${ }^{19}$

Die beoordeling van die regverdigbaarheid van ' $n$ beperking geskied in twee fases. Eers moet bepaal word of die fundamentele reg wat ter sprake is, geskend is, waarná vasgestel moet word of die skending ooreenkomstig die maatstawwe wat in artikel 36 uiteengesit is, regverdigbaar is..$^{20}$

Godsdiensverwante grondwetlike regsbeskerming kom ook in artikel 31 van die Grondwet ter sprake -

(1) Persone wat aan 'n kultuur-, godsdiens- of taalgemeenskap behoort, mag nie die reg ontsê word om, saam met ander lede van daardie gemeenskap -

(a) hul kultuur te geniet, hul godsdiens te beoefen en hul taal te gebruik nie; en

(b) kultuur-, godsdiens- en taalverenigings en ander organe van die burgerlike gemeenskap te vorm, in stand te hou en daarby aan te sluit nie.

(2) Die regte in subartikel (1) mag nie uitgeoefen word op 'n wyse wat met enige bepaling van die Handves van Regte onbestaanbaar is nie.

Die interne beperking neergelê in subartikel (2) plaas hierdie stel regte in 'n ondergeskikte posisie in vergelyking met die ander fundamentele regte. Die ontsegging van die reg om met ander lede van 'n godsdiensgemeenskap hul godsdiens te beoefen of 'n godsdiensvereniging ("association" in die Engelse teks) te stig, kan dus moontlik ook geregverdig word onder omstandighede waar dit gedoen word om redelike en rasionele stappe van staatsweë moontlik te maak om gesondheidsdienste in krisissituasies ingevolge artikel 27 te voorsien -

(1) Elkeen het die reg op toegang tot ... (a) gesondheidsorgdienste ...

(2) Die staat moet redelike wetgewende en ander maatreëls tref om binne sy beskikbare middele elk van hierdie regte in toenemende mate te verwesenlik.

Die regmatige beperkbaarheid van godsdiensverwante regte word ook wesenlik deur artikel 9(3) van die Grondwet (die algemene gelykheidsbepaling) geraak. Daarin word die staat verbied om regstreeks of onregstreeks onbillik ("unfairly") teen iemand te diskrimineer op grond van (onder meer) godsdiens, gewete, oortuiging of kultuur ("religion, conscience, belief, culture" in die Engelse teks). Artikel 37(5) verleen (in verband met noodtoestande) bykomende beskerming aan hierdie reg deur die "religion"-gedeelte daarvan as een van die fundamentele regte wat tydens 'n grondwetlik-verklaarde noodtoestand as "nie-verminderbaar" ("nonderogable") te lys.

\section{DIE BESTUUR VAN DIE KRISIS VAN 2020}

\subsection{Beperkingsmaatreëls}

Op 15 Maart 2020 het die hoof van die Nasionale Rampbestuursentrum (wat in die agtergrond verdwyn het nadat die NCCC tot stand gebring is) aangekondig dat hy die Covid-19-pandemie as nasionale ramp geklassifiseer het. Tegelykertyd, en in dieselfde Staatskoerant, ${ }^{21}$ het die minister van Samewerkende Regering en Tradisionele Aangeleenthede, aan wie die president

\footnotetext{
19 Christian Education South Africa v Minister of Education 2000 (4) SA 757 (CC), para 31.

$20 \quad$ Sv Zuma 1995 (2) SA $642(\mathrm{KH})$ par. 21.

$21 \quad$ Staatskoerant 43096 van 15 Maart 2020.
} 
die administrasie van die Wet op Rampbestuur opgedra het, 'n ramptoestand ingevolge die Wet verklaar. Op dieselfde dag het die president ook aangekondig dat hy die NCCC tot stand gebring het om alle aspekte van die staat se noodreaksie op die krisis te koördineer.

Op 25 Maart het die minister regulasies uitgevaardig ingevolge waarvan enige plek of perseel wat normaalweg oop is vir die publiek waar godsdienstige, kulturele en ander aktiwiteite mag plaasvind, vir die publiek gesluit is. ${ }^{22}$

Hierdie verbod is op 28 Mei 2020 gewysig. ${ }^{23}$ Die nuwe regulasie 37 het soos volg gelui:

Gatherings

37. (1) All gatherings are prohibited except a gathering at -

(a) a faith-based institution, which is limited to 50 persons or less, depending on the size of the place of worship:

Provided that all health protocols and social distancing measures are being adhered to as provided for in directions that must be issued by the Cabinet member responsible for cooperative governance and traditional affairs:

(b) a funeral, subject to regulation 35 .

Op dieselfde dag het die minister die direktiewe waarna regulasie 37(1)(a) verwys het, uitgereik. ${ }^{24}$ Daarvolgens is godsdienstige organisasies aangemoedig (paragraaf 3(2)), eerstens, om waar moontlik byeenkomste virtueel (aanlyn en sosiale media) byeen te roep; tweedens is die basiese verbod behou, maar is as uitsondering wel toegelaat om godsdienstige byeenkomste in plekke van aanbidding (gedefinieer as kerke, sinagoges, moskees, tempels "and other recognized places of worship") te hou op voorwaarde dat daar aan 'n reeks vereistes voldoen word. Die verantwoordelikheid vir die nakoming van die voorwaardes is geplaas op "religious leaders" en "persons in charge of places of worship". Die belangrikste voorwaardes (genoem "protocols") was die volgende:

- 'n Maksimum van 50 persone mag 'n godsdienstige byeenkoms bywoon.

- Godsdienstige dienste mag nie langer as twee uur duur nie, en tussen dienste moet daar 'n pouse van ten minste 30 minute wees.

- Streng maatreëls moet getref word om die verspreiding van Covid-19 te voorkom en te beveg, waaronder die toetsing van elkeen teenwoordig vir simptome van die virusinfeksie, die isolasie en afvoer van elkeen wat simptome toon, die deurlopende dra van mond- en neusmaskers van almal teenwoordig, voorsiening aan almal teenwoordig van ontsmettingsmiddels, die handhawing van "sosiale afstande" en die hou van 'n register van almal wat die diens bywoon.

\subsection{Inbreuk op godsdiensverwante regte}

Uit die maatreëls wat in 2020 tydens die verklaarde ramptoestand van staatsweë getref is, kan die volgende wyses waarop op die grondwetlike reg op godsdiensvryheid inbreuk gemaak is, geïdentifiseer word:

- Lede van geloofsgemeenskappe is van 25 Maart tot 1 Junie 2020 die reg wat deur artikel 31(1)(a) van die Grondwet beskerm word om hul godsdiens saam met ander lede van sulke gemeenskappe te beoefen, ontsê.

\footnotetext{
$22 \quad$ Staatskoerant 43148 van 25 Maart 2020, Bylae D.

23 Staatskoerant 43364 van 28 Mei 2020.

24 Staatskoerant 43365 van 28 Mei 2020.
} 
- Met ingang 1 Junie 2020 is die verbod op (onder meer) godsdienstige byeenkomste opgehef, maar die uitoefening van die reg om godsdiens saam met ander mense te beoefen, is wesenlik beperk deur die uitoefening daarvan onderhewig te maak aan streng voorwaardes.

- Tydens die algemene verbod op vrye beweging tydens die grendelperiode ("period of lockdown") sou gearresteerde, aangehoue en beskuldigde persone se reg ingevolge artikel 35(2)(f)(iii) van die Grondwet om deur 'n godsdiensraadgewer van eie keuse besoek te word, nie uitgeoefen kon word nie. ${ }^{25}$

Die vraag of die rampbestuursmaatreëls die basiese reg op godsdiensvryheid, soos dit deur artikel 15(1) van die Grondwet beskerm word, en die verbod op onbillike diskriminasie ingevolge artikel 9 geskend het, moet negatief beantwoord word. Die maatreëls en owerheidsoptrede wat tussen 25 Maart en 1 Junie van toepassing was, het geen onderskeid getref tussen verskillende geloofsoortuigings nie (behalwe moontlik tussen gelowiges en ongelowiges), en byeenkomste van gelowiges is nie as sodanig uitgesonder nie, maar was van toepassing op alle byeenkomste. Die verligting van die maatreëls rakende godsdiensbyeenkomste vanaf 1 Junie kan moontlik as diskriminerend gekonstrueer word teen diegene wat op 'n ander plek as 'n erkende plek van aanbidding byeen wil kom vir die beoefening van hul godsdiens, of selfs om agnostisisme of ateïsme in groepsverband te bevorder, en nie toegelaat word om dit te doen nie.

Of die maniere waarop daar tydens die pandemiekrisis op godsdiensverwante regte inbreuk gemaak is, regtens regverdigbaar is, verg oorweging van die betrokke maatreëls teen die breë agtergrond van die Grondwet.

\section{REGVERDIGING VAN DIE BEPERKING VAN GODSDIENSVERWANTE REGTE TYDENS KRISISSE}

Benewens die algemene oorwegings rakende die beperking van fundamentele regte wat in afdeling 2 hier bo bespreek is, moet die voorskrifte vir die vertolking van die Handves van Regte wat in artikel 39 van die Grondwet neergelê is, in berekening gebring word. 'n Afrikaanse weergawe van die tersaaklike dele van hierdie bepaling lui soos volg:

(1) By die uitleg van die Handves van Regte -

(a) moet 'n hof, tribunaal of forum die waardes wat 'n oop en demokratiese samelewing gebaseer op menswaardigheid, gelykheid en vryheid ten grondslag lê bevorder; ...

(2) By die uitleg van enige wetgewing, en by die ontwikkeling van die gemene reg of gewoontereg, moet elke hof, tribunaal of forum die gees, strekking en oogmerke van die Handves van Regte bevorder.

Selfs 'n oppervlakkige oorweging van hierdie bepalings maak dit duidelik dat daar heelwat ruimte by artikel 39 ingebou is vir subjektiewe meningsverskille oor die vertolking van die Handves: waterdigte definisies vir of vaste inhoudgewing aan konsepte soos "'n oop en demokratiese samelewing", "menswaardigheid", "gelykheid" en "vryheid" bestaan nie, en presies wat die "gees, strekking en oogmerke" van die Handves is, bly oop en debatteerbaar. Regulasie 11B soos ingevoeg deur die ministeriële wysigingsregulasies in Goewermentskennis-
gewing R.398 in Staatskoerant 43148 van 25 Maart 2020. 
In 2006 skryf Stu Woolman en Henk Botha oor die normatiewe inhoud van die beperkingsanalise wat deur artikel 39 vereis word:

That normative content for limitations analysis turns on the phrase "an open and democratic society based on human dignity, equality and freedom". Determining the meaning of this phrase is fraught with interpretive difficulties as old as political theory itself. There are, for starters, the tensions between democracy and rights, between equality and freedom, and the deeply contested nature of each of these terms. ${ }^{26}$

In die regspraak en literatuur is daar sedert 2006 ook nie juis verdere vordering gemaak om helderheid oor die betekenis van hierdie vloeibare konsepte te bring nie. Die onvastheid van die inhoud van hierdie begrippe en konsepte bring egter nie mee dat enige subjektiewe of bevooroordeelde vertolking toelaatbaar sal wees nie, want die manier waarop dit (veral in regspraak) gebruik word, sal ten minste gemotiveer moet word. Nietemin is die konkrete toepassing daarvan van geval tot geval telkens relatief oop vir die betrokke forum se voorkeur en oordeel. Dit verleen die gewenste elastisiteit, maar kan ook problematies wees: gegewe die werklikheid van voortdurende verandering van die omstandighede waarin die gemeenskap leef (langs 'n breë kontinuum vanaf stabiele normaliteit, deur maatskaplike spanning en onsekerheid, tot by uiterste krisisse), kan 'n plooibare vertolking noodsaaklik wees. Wanneer die interpretasie egter dogmaties, of ideologies eensydig, aangepak word, word objektiwiteit en waarskynlik ook gebalanseerde geregtigheid opgeoffer.

Die beperking van godsdiensverwante regte is, selfs onder "normale" omstandighede, op sy beste 'n omstrede aangeleentheid. Vanselfsprekend is dit so, onder meer omdat geloofsoortuigings onlosmaaklik en intiem verbonde is aan menswees, omdat dit so uiteenlopend is van persoon tot persoon en van gemeenskap tot gemeenskap, omdat die manier waarop mense hul geloofsoortuigings uitleef dikwels die potensiaal het om inbreuk te maak op ander se regsaansprake en omdat algemene regsvoorskrifte strydig kan wees met mense se fundamentele lewensbeskoulike sienings. In die regspraak en literatuur is daar veelvuldige internasionale en Suid-Afrikaanse voorbeelde van omstredenheid betreffende beperkings op die reg op godsdiensvryheid. ${ }^{27}$ Onlangse Suid-Afrikaanse voorbeelde het betrekking op skole se godsdiensbeleid, ${ }^{28}$ godsdienstige kleredrag in skole ${ }^{29}$ en kerkreg. ${ }^{30}$

Of meer beperkings op die beoefening van godsdiens tydens krisisse wat aanleiding gee tot noodtoestande en ramptoestande toelaatbaar behoort te wees, is nie vanselfsprekend nie. Die aard van die godsdiensverwante regte bring mee dat beperkings daarop weens 'n krisissituasie nouliks geregverdig sal kan word as die uitoefening van sodanige regte nie die oorsaak is van of kan bydra tot die krisis nie. Om die waarheid te sê, aangesien dit onmoontlik

26 Woolman, S \& Botha, H. Limitations. In Woolman \& Bishop (eds). Constitutional Law of South Africa. $2^{\text {nd }}$ ed. Cape Town: Juta. Vol 2, pp. 34-113.

27 Sien bv. Henrico, R. 2019. Proselytising the Regulation of Religious Bodies in South Africa: Suppressing Religious Freedom? PER/PELJ, 22:1-27.

28 Sien bv. De Freitas, SA. \& Du Plessis GA. 2018. Organisasie vir Godsdienste-Onderrig en Demokrasie v Laerskool Randhart et al.: The right to freedom of religion, diversity and the public school. Journal for Juridical Science, 43(2):32-52.

29 Sien bv. Osman, F \& Wilké, J. 2018. Dress Codes in Schools: A Tale of Headscarves and Hairstyles. Obiter, 39(3):585-601.

30 Sien bv. Sutton, W \& Sutton, L. 2019. Regsgevolge volgens die Gaum-saak vir nienakoming van kerkordelike prosedures ten opsigte van besluite deur die Algemene Sinode van die Nederduitse Gereformeerde Kerk." LitNet Akademies, 16(2):397-421. 
is om mense se fundamentele subjektiewe oortuigings, soos dit deur artikel 15(1) van die Grondwet verskans is, met regsmiddele voor te skryf of te verander, kan die basiese reg op godsdiensvryheid nie as sodanig beperk word nie. Wat artikel 15(1) wel verbied, is staatsoptrede (soos wetgewing) wat bedoel is om bepaalde subjektiewe oortuigings wederregtelik te verklaar en, saamgelees met die diskriminasieverbod van artikel 9(3), een of meer soorte oortuigings te bevorder of toe te laat, en ander nie. Uiteindelik vereis artikel 15(1) dus dat daar geen struikelblokke in die weg van mense geplaas mag word om te glo wat hulle wil nie.

Dit is egter ' $n$ ander saak wanneer dit kom by die uitlewing van godsdienstige oortuigings, wat deur artikel 31 van die Grondwet beskerm word. Die aard van die krisis wat beperkings op die uitlewingsregte plaas, sal deurslaggewend wees vir die regverdigbaarheid van die beperkings daarop. As die krisis veroorsaak word deur die manier waarop 'n godsdiensgroep of -groepe hul oortuigings uitleef (byvoorbeeld opsweping tydens godsdienstige byeenkomste om 'n ander groep of lede daarvan te benadeel of aan te val of om die sosiale orde te versteur), is dit denkbaar dat ' $n$ verbod op, of ' $n$ beperking van, godsdienstige byeenkomste regverdigbaar sal wees (ook in die lig van die verbod in artikel 16(2) van die Grondwet op haatspraak). Sonder so 'n verband tussen die betrokke krisis en die uitlewing van godsdienstige oortuigings word dit egter moeiliker om beperkings daarop te regverdig.

Artikel 27(3) van die Wet op Rampbestuur veroorloof die uitreik van regulasies en direktiewe tydens 'n ramptoestand slegs tot die mate waartoe dit nodig is vir die doel om die publiek by te staan en te beskerm, verligting aan die publiek te verleen, eiendom te beskerm, ontwrigting ("disruption") te voorkom of te bekamp of die vernietigende ("destructive") en ander gevolge van die ramp te hanteer. Om 'n verbod op, of die uitlewing van, godsdiens, soos in artikel 31 van die Grondwet bedoel, tydens die ramptoestand te regverdig, sal dus vereis dat ten minste een van die toetse van artikel 27(3) van die Wet geslaag word. Die regverdigbaarheid van die verbod van 25 Maart 2020 op godsdienstige byeenkomste is kort na die uitreiking daarvan in die hooggeregshof in Pretoria getoets. In haar uitspraak het die regter die gevolg van die verbod soos volg beskryf:

As a result, the Zion Christian church gathering in Moria could not take place, Pesach could not be celebrated in Synagogue nor could the ritual of friends and family together at sedar take place at home; Holy Communion and mass had to be foregone by Catholics and Easter could not be celebrated in church services throughout the country. In fact, each religious sector of the country had to make tremendous sacrifices for the greater good. ${ }^{31}$

Die applikante (Moslems wat erken het dat hul siening nie met dié van die meerderheid Moslems in die land gestrook het nie) het aangevoer dat die maatreëls wat getref is hul regte op bewegingsvryheid, godsdiensvryheid, vryheid van assosiasie en menswaardigheid aangetas het en dat die grendelregulasies die verrigting van wat hulle as verpligte godsdienstige handelinge beskou, gekriminaliseer het, waardeur hulle voor die keuse geplaas is om volgens hul oortuiging of ooreenkomstig die regsvoorskrifte op te tree. Die hof het bevind dat die sluiting van plekke van aanbidding ingevolge die ministeriële regulasies redelik en regverdigbaar was, met die volgende motivering:

In my view, in South Africa right now, every citizen is called upon to make sacrifices to their fundamental rights entrenched in the Constitution. They are called upon to do so in the name of "the greater good", the spirit of "ubuntu" and they are called upon to do so

31 Mohamed $v$ President of the Republic of South Africa (case number 21402/20 in the High Court, Gauteng Division, Pretoria). 
in ways that impact on their livelihoods, their way of life and their economic security and freedom. Every citizen of this country needs to play his/her part in stemming the tide of what can only be regarded as an insidious and relentless pandemic. ${ }^{32}$

In die veelbesproke uitspraak van dieselfde hof 'n maand later het regter Davis die feit dat reise om geliefdes by hul sterfbed by te staan, verbied is, terwyl reise na en bywoning van daaropvolgende begrafnisse toelaatbaar was, as 'n voorbeeld voorgehou dat die regulasies irrasioneel was. ${ }^{33}$ Gevolglik is bevind dat feitlik al die regulasies in stryd was met die Grondwet en dus ongeldig was. Dit is egter van belang dat hierdie bevinding nie berus het op 'n vertolking dat die regulasies godsdiensvryheid geskend het nie, maar dat die reg op vreedsame byeenkoms en assosiasie aangetas is. ${ }^{34}$ Die vraag of die hof die toepaslike regsmaatstawwe, veral rakende rasionaliteit en redelikheid, korrek vertolk het, het spoedig kommentaar uitgelok. ${ }^{35}$

Ten spyte daarvan dat dit uiteindelik mag blyk dat die Wet op Rampbestuur verkeerdelik deur die regering aangewend is, dat die ruimte wat van die bepalings daarvan gelaat het vir ongeoorloofde en moeilik kontroleerbare staatsoptrede wat tot die ongrondwetlikheid daarvan gelei het en dat die totstandbrenging, besluite en optrede van die NCCC onregmatig was, is dit hoogs onwaarskynlik dat enigiemand daarin sal kan slaag om die howe daarvan te oortuig dat die staat tydens die pandemiekrisis hul godsdiensverwante regte wederregtelik geskend het.

\section{SLOTBESINNING}

Omdat die staat as owerheid die verantwoordelikheid dra om krisissituasies te hanteer deur die regsorde met die regsgereguleerde gebruik van gesag te handhaaf, is enige besinning oor die beperking van die reg op godsdiensvryheid tydens krisistye afhanklik van die waarnemer se staatsbegrip. Hierdie oorweging is geen oordrewe sprong na die teoretiese nie, want in verskillende regsordes word staatsgesag op uiteenlopende wyses geregverdig en word die rol van die staat in religieuse aangeleenthede op verskillende maniere verstaan. Op die mees grondliggende vlak gaan dit oor die onderliggende siening van die bron van staatsgesag. Om hier in te gaan op die spektrum van nuanses oor staatsbeskouings is nie moontlik nie. Die volgende uitstekende samevatting in 'n meestal vergete Afrikaanse boek met besondere meriete dien egter die huidige doel:

Terwyl die ontstaan van die staat volgens Aristoteles in die sosiale geneigdheid van die mens geleë is, verklaar die kontrakteoretici (Hobbes Rousseau, Locke, De Groot) die ontstaan van die staat deur middel van 'n sosiale verdrag. Naas die oorspronklike verdrag gebruik De Groot ook die natuurreg om die ontstaan van die staat, asook die mag wat die owerheid oor die onderdane het, te verklaar. In teenstelling met die regspositiwisme huldig De Groot die opvatting dat die positiewe reg aan die hand van die natuurreg getoets kan word om te bepaal of dit regverdig of onregverdig is.

$32 \quad$ Para 75 van die Mohamed-uitspraak.

33 De Beer v Minister of Cooperative Governance and Traditional Affairs (case number 21542/2020 in the High Court, Gauteng Division, Pretoria), para 7.

$34 \quad$ Die De Beer-uitspraak, para 8.

35 Sien bv. Labuschaigne, M \& Staunton, C. 2020. COVID-19: State of disaster in South Africa. Verfassungsblog. https://verfassungsblog.de/covid-19-state-of-disaster-in-south-africa/ [11 April 2020], en Calland, R. 2020. Court throws South Africa's lockdown exit strategy into disarray. But it got it wrong. https://theconversation.com/court-throws-south-africas-lockdown-exit-strategyinto-disarray-but-it-got-it-wrong-139991 [4 Junie 2020]. Die regering het appèl aangeteken teen hierdie uitspraak. 
Volgens Rawls vervul die regsbeginsels wat by die oorspronklike verdrag gekies word die funksie van 'n permanente, kritiese maatstaf vir die beoordeling van die positiewe reg. Kelsen voer die geldigheid van regsnorme terug na 'n hipotetiese of fiktiewe basisnorm (wat die spits van die piramide van die positiewe reg is) en ontken dat regsnorme aan die hand van waardes getoets kan word.

Marx en Engels koppel die ontstaan van die staat (wat niks anders as 'n onderdrukkingsinstrument in die hande van die ekonomies sterkste klas is nie) aan die beskerming van privaat eiendom wat in die kommunistiese fase saam met die staat oorbodig word. Hitler verklaar die ontstaan van die staat uit die organiese groei van 'n volksgemeenskap en die staat is die totalitêre politieke vorm waarbinne die volk homself organiseer. ${ }^{36}$

Die beskouing wat staatsteorieë globaal sedert die Tweede Wêreldoorlog domineer, is die liberale demokrasie. 'n Tipiese siening van die rol van die reg rakende religie is soos volg deur Russell Sandberg verwoord: "The official narrative of the law sees law as neutral and objective and independent of religion." Die Amerikaners noem dit "a wall of separation between church and state". ${ }^{37}$

In Suid-Afrika (soos in verskeie ander lande) lê die regsdogmatiese en politieke spanningslyne oor staatsgesag aan die een kant tussen sosialisme (soos dit oor meer as twee dekades deur die ANC nagestreef word) en die liberale demokrasie waarop die Grondwet grootliks gefundeer is aan die ander kant. 'n Verklaring vir die eienaardighede verbonde aan die manier waarop die regering die pandemiekrisis van 2020 benader het, is in hierdie spanning te vinde: daar is 'n dogmatiese drang na sosialistiese sentralisering (waarvan die NCCC 'n sprekende voorbeeld is), terwyl blatante skending van die essensieel liberale Grondwet nie tans polities geleë is nie.

Wat betref die beperking van godsdiensvryheid deur die staat, hetsy tydens krisisse of andersins, bly dit onmoontlik om die eeueoue vraag of dit wat regtens en grondwetlik geoorloof is, versoen kan word met burgers se religieuse oortuigings, simplisties te beantwoord. Antwoorde daarop hang vanselfsprekend af van die uiteenlopende religieuse oortuigings wat in ' $n$ religieus-plurale samelewing teenwoordig is. Dit is nie moontlik om hier ' $n$ oorsig van verskeie religieuse sienings hieroor te bied nie, maar as een voorbeeld word ten slotte wel enkele algemene beginsels uit 'n Christelike perspektief uitgelig.

Uit die aard van die Christelike geloof (soos dit onder meer uit 1 Korintiërs 2:3-5 blyk) is die oortuigings van gelowiges van staatsweë prakties en prinsipieel onaantasbaar: Christelike geloof spruit nie voort uit menslike (dus ook nie staatlike) regulering of druk nie. Gebaseer op die Pauliniese riglyne weergegee in veral Romeine 13:1-7, kan die burger se plig om die voorskrifte van die staatsowerheid wat op die goeie orde gemik is, na te kom, nie ontken word nie. Dat 'n staatlike verbod op godsdienstige byeenkomste (hoe ook al gemotiveer) Christene van hul vermoë om hul godsdiens te beoefen, ontneem, is nie vanselfsprekend nie geloofsbelewing is in die eerste plek persoonlik, en wat gemeenskaplike geloofsbelewing betref, sluit Matteus 18:20 ("twee of drie in my Naam saam") sekerlik nie virtuele "saamwees" (byvoorbeeld telefonies of met behulp van die internet) uit nie. Of die uitoefening van

$36 \quad$ Van Niekerk, P. 1996. Regering en staatsgesag: Die staat, die reg en die politiek. In Wiechers \& Bredenkamp (reds). Die staat: Teorie en praktyk. Pretoria: JL van Schaik Akademies, pp.139-162, 162.

37 Sandberg, R. 2018. Snakepits \& sandpits. In Ahdar, R. (ed.). Research Handbook on Law and Religion. Cheltenham, Edward Elgar Publishers, pp. 16-36, 16. 
staatsgesag wat godsdiensvryheid beperk onder "normale" of krisissituasies plaasvind, verander nie die betrokke beginsels nie.

Wat ten slotte vasstaan, is dat daar altyd uiteenlopende standpunte sal wees oor waar die grens tussen staatsgesag en godsdiens behoort te lê. Salus populi suprema lex en Gloria Dei suprema lex kan nie tegelyk geld nie, want daar kan net een "hoogste reg" wees, ook in krisistye.

\section{BIBLIOGRAFIE}

Currie, I \& De Waal, J. 2014. The bill of rights handbook. Cape Town: Juta.

De Freitas, SA. \& Du Plessis GA. 2018. Organisasie vir Godsdienste-Onderrig en Demokrasie v Laerskool Randhart et al.: The right to freedom of religion, diversity and the public school. Journal for Juridical Science, 43(2):32-52.

Du Plessis, W \& Olivier, N. 1987. Verdere beperkende noodmaatreëls. SA Publiekreg/Public Law, 2(1):84-88.

Du Plessis, W \& Olivier, N. 1987. Tweede algemene noodtoestand. SA Publiekreg/Public Law, 2(2):197207.

Erasmus, G. 1994. In Van Wyk et al. (eds). Rights and constitutionalism - The new South African legal order. Cape Town: Juta.

Henrico, R. 2019. Proselytising the regulation of religious bodies in South Africa: Suppressing religious freedom? PER/PELJ, 22:1-27.

Mathews, AS. 1977. Law, order and liberty in South Africa. Cape Town: Juta.

Moon, R. (ed.). 2008. Law and religious pluralism in Canada. Vancouver: UBC Press.

Osman, F \& Wilké, J. 2018. Dress codes in schools: A tale of headscarves and hairstyles. Obiter, 39(3):585-601.

Sandberg, R. 2018. In Ahdar, R. (ed). Research handbook on law and religion. Cheltenham: Edward Elgar Publishers.

Sutton, W \& Sutton, L. 2019. Regsgevolge volgens die Gaum-saak vir nienakoming van kerkordelike prosedures ten opsigte van besluite deur die Algemene Sinode van die Nederduitse Gereformeerde Kerk." LitNet Akademies, 16(2):397-421.

Van Niekerk, P. 1996. Regering en staatsgesag: Die staat, die reg en die politiek. In Wiechers \& Bredenkamp (reds). Die staat: Teorie en praktyk. Pretoria: JL van Schaik Akademies.

Venter, F. 1988. Krygswet en noodtoestand. SA Publiekreg/Public Law, 3(1):1-22.

Venter, F. 2015. Constitutionalism and religion. Cheltenham: Edward Elgar Publishers.

Venter, F. 1977. Salus reipublicae suprema lex. Tydskrif vir Hedendaagse Romeins-Hollandse Reg, 40:233-252.

Venter, F. 1988. Krygswet en noodtoestand. SA Publiekreg, 3(1):1-22.

Venter, F. 2020. Staatsregtelike behoorlikheid in die 21ste eeu. Tydskrif vir Geesteswetenskappe, 60(3):579-595.

Woolman, S. \& Botha, H. 2006. Limitations. In Woolman \& Bishop (eds). Constitutional Law of South Africa. 2nd ed. Cape Town: Juta.

\section{Gewysdes}

Christian Education South Africa v Minister of Education 2000 (4) SA 757 (CC).

De Beer v Minister of Cooperative Governance and Traditional Affairs (case number 21542/2020 in the High Court, Gauteng Division, Pretoria).

Freedom Front Plus v President of the Republic of South Africa (22939/2020) [2020] ZAGPPHC 266 (6 July 2020).

Khosa v Minister of Defence and Military Veterans (case number 21512/2020 in the High Court, Gauteng Division, Pretoria).

Mohamed v President of the Republic of South Africa (case number 21402/20 in the High Court, Gauteng Division, Pretoria). 
S v Baker; $S v$ Doyle [1965] 1 All SA $362(\mathrm{~W})$.

$S v$ Essop 19732 SA $815(\mathrm{~T})$.

S v Zuma 1995 (2) SA $642(\mathrm{KH})$.

\section{Kommissieverslag}

Verslag van die Kommissie van Ondersoek na Aangeleenthede betreffende die Veiligheid van die Staat (die "Potgieter-kommissieverslag") RP 102/1971.

\section{Internetbronne}

Calland, R. 2020. Court throws South Africa's lockdown exit strategy into disarray. But it got it wrong. https://theconversation.com/court-throws-south-africas-lockdown-exit-strategy-into-disarray-butit-got-it-wrong-139991 [4 June 2020].

International Monetary Fund. 2020. Policy responses to Covid-19 https://www.imf.org/en/Topics/imfand-covid19/Policy-Responses-to-COVID-19 [4 June 2020].

Labuschaigne, M. \& Staunton, C. 2020. COVID-19: State of disaster in South Africa. Verfassungsblog. https://verfassungsblog.de/covid-19-state-of-disaster-in-south-africa/ [11 April 2020].

RHK Attorneys. 2020. https://www.scribd.com/document/460238622/RHKAttorneys04May20\#download\&from_embed [4 June 2020].

SAFLII. 2020. http://www.saflii.org/cgi-bin/sinosrch-adw.cgi?query=COVID-19\%20or\%20 coronavirus\%20;submit=Search;view=database-natural;offset $=0$ [4 June 2020]. 